\title{
ARE THE GROUNDWATER LEVELS FALLING IN PUERTO RICO BETWEEN 1982 AND 2017: COMPARING A KARST AQUIFER WITH NON-KARST AQUIFERS
}

\author{
Ronald T. Richards \\ Universidad Ana G. Méndez, Carolina Campus and Interamerican University Bayamón Campus, Natural Sciences \\ and Technology Department \\ PO Box 2010,Carolina,PR 00984-201010,ronaldtrichards@gmail.com
}

\begin{abstract}
Puerto Rico is an oceanic tropical archipelago with about 3.2 million inhabitants, located between the Caribbean Sea and the Atlantic Ocean. It has a land area of $9104 \mathrm{~km}^{2}$. Groundwater provides about 15 percent of the freshwater used in Puerto Rico and is an important reserve during droughts. A monthly groundwater level index was calculated for Puerto Rico from 1982 to 2017. Sub-indices were calculated for the karst North Coast Limestone aquifer, the non-karst South Coastal Plain aquifer, and for the non-karst Rest of Puerto Rico. The index was calculated with data from 80 non-pumping observation wells operated by the United States Geological Survey. Each station has more than 100 water levels on the Internet. The study also looks at rainfall and demographic data that affects groundwater.
\end{abstract}

Groundwater levels in Puerto Rico, the North Coast Limestone and the Rest of Puerto Rico are rising. Groundwater levels in the South Coastal Plain aquifer are falling. The declining water levels on the south coast are probably due to changing pumping and recharge patterns and not climate change. The island shows spatial correlation. High levels of the index are associated with landslides in areas without aquifers. Low levels of the index are associated with water rationing. The index shows temporal correlation with the index rising or falling for years at a time. The index rose between 1994 and 2011. The all-time maximum was a massive rainfall event in August 2011. The second highest peak of the index was caused by Hurricane Maria on 20 September 2017. Hurricane Maria was the largest single recharge event in the 36-year period of the index. The minima of the index in 1994 and 2015 are associated with water rationing in the San Juan metropolitan area. In the final analysis, based on demographics, precipitation, and groundwater levels, the current pattern in the karst North Coast Limestone is more sustainable than in the non karst South Coastal Plain.

\section{Introduction}

Puerto Rico is an oceanic tropical archipelago, with about 3.2 million inhabitants. It is located between the Caribbean Sea and the Atlantic Ocean. The islands are a territory of the United States of America. About 15 percent of the water used in Puerto Rico comes from groundwater (Molina-Rivera 2014).

Are groundwater levels in Puerto Rico falling, holding steady, or rising? The hypothesis of this study is that groundwater levels are rising in Puerto Rico. What is the relationship between groundwater levels and destructive events on the surface like floods and water rationing? Throughout the world, climate change and changes in the economy will probably cause groundwater levels to decline in some areas and rise in others. This paper will look at how Puerto Rico fits into global trends.

With a production well, when the groundwater level drops below the level of the pump it will be abandoned, thus reducing access to water. The abandoned well may be replaced with a deeper well. Decreasing groundwater levels can raise the cost of energy to pump it to the surface. All the major aquifers in Puerto Rico are coastal and in a coastal aquifer lowering groundwater levels can cause saline water intrusion from the ocean. The lowering of the groundwater levels can mobilize low quality water that is deeper in the aquifer. In the long run declining groundwater levels in an aquifer can result in less available, higher cost, and lower quality water.

On Earth two billion people drink groundwater. Groundwater is used to produce 40 percent of the global food supply. Cities with more than 12 million people that depend on groundwater for 25 percent or more of their water supply include Mexico City, Kolkata, Tehran, Shanghai, Buenos Aires and Jakarta (Morris et al. 2003). 
The concentration of carbon dioxide in the atmosphere is increasing and this will cause the atmosphere and the oceans to become warmer. Warmer water in the oceans will lead to more evaporation. The atmosphere has virtually no storage capacity and increased evaporation will lead to the average rainfall on Earth increasing. Even as the average rainfall on Earth increases, many wind and current patterns will change, and some areas will probably experience decreasing amounts of rain. Rainfall may also become more erratic with floods and droughts both becoming more common.

Popular conception is that groundwater levels are falling in all parts of the world. Two aquifers famous for falling groundwater levels are the Ogallala in the central United States and the Punjab that crosses the border between India and Pakistan. In places the groundwater levels in the Ogallala have declined by $30 \mathrm{~m}$ (Kornikov 2013). In the Punjab groundwater levels are falling $600 \mathrm{~mm} /$ year and the nitrate concentration has increased 10-fold (Yadav 2012). Both areas are highly productive areas to grow wheat and other crops. In Puerto Rico the use of furrow irrigation had the unintended consequence of artificially increasing the recharge to the non-karst South Coastal Plain aquifer (SCP). The change to drip irrigation saves water but reduces the recharge to the aquifer.

Groundwater levels are rising in many large cities as industrial production and groundwater production have moved away from the city center. Groundwater contamination has caused many wells near cities to be closed. In cities such as London, Barcelona, Moscow, and Riyadh groundwater levels are rising (Morris et al. 2003). Rising groundwater levels can cause flooding of underground facilities that then need to be pumped. In Puerto Rico the closing of factories, sugar mills, and steam-operated railroads has led to decreased groundwater production in some areas.

The climate will change. The economy will change. In some areas, groundwater levels will rise, and some areas groundwater levels will fall. Long-term groundwater level data are needed from many parts of the world to understand how this valuable resource will be affected by these changes. The population of Puerto Rico has been declining for more than a decade as people move to other parts of the USA to look for work. The last time that the population of Puerto Rico declined was in the 16 th century when the native Tainos died of European diseases brought by the Spanish conquistadors. The population decline of the 16th century is poorly documented. In 1765, a census carried out by the Spanish government found 44,883 people. With every census the population rose until the census of the US government found $3,808,610$ in 2000 . The population declined to $3,725,787$ in 2010, a decline of 2.2 percent (US Census Bureau 2020).

On 5 October 1985, a massive rainfall event caused the most lethal landslide in the history of the USA. A mudslide buried the working-class community of Mameyes, Ponce and killed an estimated 130 people (Silva-Tulla 1986). Besides the landslide there were deaths when a bridge collapsed and when a community flooded for a total of about 180 people.

On 20 September 2017, Hurricane Maria, a category 4 storm, crossed Puerto Rico. It was the worst hurricane in Puerto Rico since 1928. Hurricane Maria caused the complete collapse of modern society. There was no electricity, telecommunications, transportation, newspapers, postal services, radio and TV stations went off the air, and supplies of food, water, gasoline, propane, cash, and medicine were very limited. After almost a year of debate the most definitive study puts the death toll at almost 3000 people (Santos-Burgoa et al. 2018). More than three million people lost power and for about half the power was out for three months. It was the second largest power blackout in the world. The largest power blackout in world history was caused by Typhoon Haiyan hitting the Philippines in November 2013 (Criss 2018). Hurricanes, typhoons, and cyclones are different names for the same atmospheric phenomena. Presumably Typhoon Haiyan raised groundwater levels in the Philippines. The two-day rainfall totals ranged from 129 to $963 \mathrm{~mm}$. The long-term effect on the population is unknown. About 200,000 people left the island after the hurricane and it is unknown how many will return as the situation returns to normal (Hernández 2018). How did the rainfall of that caused the Mameyes landslide and Hurricane Maria affect the levels of groundwater?

In the years after Hurricane Maria drought is returning to the island of Puerto Rico. As of 27 August 2019, the US Drought Monitor classifies 21 percent of the island as being moderate to severe drought. The dry area is in the southwest of the island. Puerto Rico has limited storage and in less than a year after the massive rain of Hurricane 
Maria water is scarce in some areas (Helm 2018). Lago Guajataca is a reservoir located on the Río Guajataca in northwest Puerto Rico. For about three months in the spring of 2019, water rationing affected customers served by the reservoir. In the affected area people had one day with water and one day without (Notiuno630AM 2019).

Most of the water for the San Juan metropolitan area comes from Lago Carraizo, which is a reservoir fed by the Río Grande de Loiza and Lago La Plata, which is a reservoir fed by the Río de la Plata. In 1994 and 2015 low water levels in the reservoirs caused water rationing. At the height of water rationing many homes had water for two days per week (Janssen 2015). Groundwater is an important reserve when surface water is unavailable due to drought. The aquifers tend to be in coastal areas and not in the drainage basins of the major rivers. If a drought was of small scale than one river could have water rationing, but the groundwater levels would not be affected. If the drought covers the whole island, then periods of water rationing will be associated with low groundwater levels.

El Yunque mountain in northeast Puerto Rico is the wettest part of the island and the south and southwest are in its rain shadow. It is obvious that the SCP is drier than other parts of Puerto Rico. The vegetation is more xeric, cacti are more common. The rivers are ephemeral, and brushfires are more common. In the January to March dry season the median strip of the divided highway often is brown while it is green in San Juan. The National Weather Service has published a map of the average annual rainfall between 1981 and 2010 (NWS 2018). This map was used to estimate the average annual rainfall at each of the 80 stations used in this study. The karst North Coast Limestone (NCL) has 73 percent more rain than the non-karst SCP. Over the last 120 years numerous changes have been to the flow of water in the SCP. Lago Carite is a manmade reservoir on the headwaters of the north-flowing Río de la Plata. The project was completed in 1913 and includes a tunnel to divert water to the SCP for irrigation. When sugarcane is watered with furrow irrigation about 30 percent of the water infiltrates and recharges the aquifer. When water is diverted from northward flowing streams to the south via tunnels, the net effect was that the water levels in the aquifer rise. (Kuniansky and Rodríguez 2010).

Rainfall is increasing at eight stations located throughout Puerto Rico. The year was divided into four seasons; dry (December to March), first rainy season (April and May), Summer Minimum (June to August), and second rainy season (September to November) for a total of 32 data points. Of the 32 data points at 29 the rainfall is rising. At Lajas in the southwest and Ponce in the south some seasons had declining rainfall although at both stations the net effect was rising rainfall. At the other six stations the rainfall is rising in all parts of the year (Martínez-Sánchez, Odalys, written communication).

The main problem with water resources in Puerto Rico is the lack of storage. Puerto Rico has more rainfall than most places on Earth but in an undammed stream, most of the rainfall is back in the ocean in 24 hours. (Richards 2016) Manmade reservoirs (called Lagos in Spanish) can store the water for months. The aquifers are very inefficient, when there are massive amounts of rain the aquifers capture a tiny fraction of the water but can store it, in some cases, for years.

Locations of the two main aquifers in Puerto Rico are shown in Figure 1. The karst NCL and the non-karst SCP are described by Renken et al. (2002). The SCP covers $474 \mathrm{~km}^{2}$ and extends $70 \mathrm{~km}$ along the south coast from Ponce in the west to Arroyo in the east and is 3 to $8 \mathrm{~km}$ wide. The flat terrain of the SCP is the most important center for agriculture in Puerto Rico. The SCP is a series of alluvial fans that have coalesced. The size of the alluvium ranges from silt to cobbles in a complex depositional environment that includes downward moving grabens. The SCP is crossed by southward flowing ephemeral rivers that lose water to the aquifer.

Three of the eight municipios that use the most groundwater are in the SCP. The combined pumping of the muncipios of Santa Isabel, Juana Díaz and Salinas is 1200 L/s (Molina-Rivera 2014). Municipios are the equivalent of counties in the USA. Compared to Puerto Rico as a whole, the SCP has about 5 percent of the land area and10 percent of the population.

The NCL stretches $120 \mathrm{~km}$ from Aguada in the west to Canovanillas in the east. In places it is $25 \mathrm{~km}$ wide. Where the limestone is overlain by unconsolidated alluvium, the terrain is flat. In the south and west where the limestone outcrops it is often very rugged. In the NCL the porosity of the aquifer has been increased by dissolution. The sediments of the NCL were laid down in the Oligocene and Miocene. The sediments slope northward 


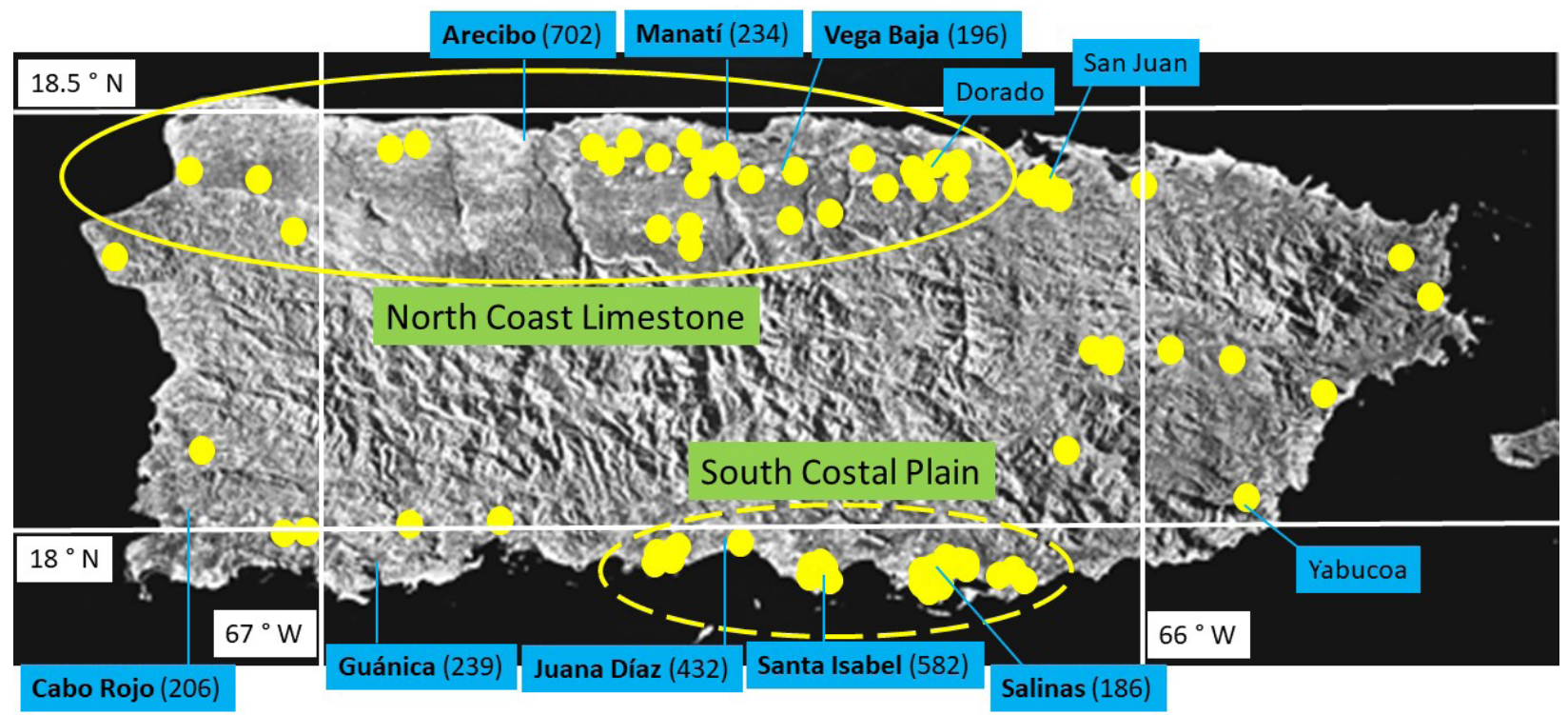

Figure 1. Map of Puerto Rico. The map shows the locations of the karst North Coastal Limestone and the non-karst South Coastal Plain aquifers. Rest of Puerto Rico is everything that is not SCP or NCL. The circles are the locations of the non-pumping observation wells used in this study. The municipios shown in bold are the eight with the highest production of groundwater, in liters per second (Molina-Rivera 2014). The municipios not in bold are others that are mentioned in the text.

at about 5 degrees. The NCL has an upper and a lower unit which are divided by the confining Cibao formation. The NCL is crossed by northward flowing permanent rivers that gain water from the aquifer. Three of the eight municipios that pump the most groundwater are in the NCL. Arecibo, Manatí, and Vega Baja have a combined pumping of $1110 \mathrm{~L} / \mathrm{s}$ (Molina-Rivera 2014).

In this paper the small, disconnected, non-karst aquifers that make up the majority of the land area of the island are called Rest of Puerto Rico (ROP). In the dry southwest part of the island the ROP includes two of the eight municipios with the most production of ground water. Table 1 gives data about the eight municipios with the highest production of groundwater. The data includes population, change of population, groundwater consumption, ranking, and the percentage that groundwater is of the total water supply for the municipio. In Puerto Rico, the per capita water consumption has been steady since 1980 (Larsen 2000).

Arecibo, in the karst NCL, pumps groundwater at 702 $\mathrm{L} / \mathrm{s}$ and is the municipio with the largest production of groundwater in Puerto Rico. It is an outlier as it has twice the population of other municipios that use groundwater. It has other sources of water and groundwater is only

\begin{tabular}{|l|l|r|r|r|r|r|}
\hline Arecibo & NCL & 96 & -3.7 & 702 & 1 & 13 \\
\hline Manatí & NCL & 44 & -2.9 & 234 & 5 & 100 \\
\hline Vega Baja & NCL & 60 & -3.7 & 196 & 7 & 100 \\
\hline Santa Isabel & SCP & 23 & 7.4 & 582 & 2 & 100 \\
\hline Juana Díaz & SCP & 51 & 0.4 & 432 & 3 & 100 \\
\hline Salinas & SCP & 31 & -0.1 & 186 & 8 & 100 \\
\hline Guánica & ROP & 19 & -11.2 & 239 & 4 & 100 \\
\hline Cabo Rojo & ROP & 51 & 8.5 & 206 & 6 & 70 \\
\hline
\end{tabular}

Table 1. The eight municipios in Puerto Rico with the highest groundwater production. The columns are municipio, region, population in thousands, population growth from 2000 to 2010 in percent, the groundwater production in liters per second, the rank of the groundwater production, and the percent of the water supplied by groundwater.

13 percent of the total municipal water supply. Between 2000 and 2010 the three municipios in the karst NCL lost an average of 3.4 percent of their population. The three muncipios in the non-karst SCP, on average gained, 2.6 percent in the same time period. The population changes in the non-karst ROP are erratic. Guánica lost 11.2 percent of its population while Cabo Rojo gained 8.5 percent. Recent events are expected to continue the population decline in Guánica. On 7 January 2020 an earthquake with a magnitude of 6.4 destroyed buildings in the area. Dozens of shocks both before and after the 
main earthquake have left people fearful that their house will collapse. As this is being written in January 2020 there are thousands of people camped out in parks or their own lawn.

Seawater is 2.5 percent denser than freshwater. Aquifers seldom have turbulent flow and mixing is low. Near the coast it is common for freshwater to float on top of the denser seawater. Very little is known about the exact elevation of saline water in most aquifers in Puerto Rico. In May 1995, borehole induction logging was used to document the elevation of the saline-freshwater interface at two non-pumping wells in the karst NCL in Dorado. Dorado is located west of San Juan and east of Vega Baja. At the San Antonio 1 well (USGS ID 182657066162700) and the Higuillar 1 well (182620066163400) the thickness of the freshwater was 63 and $78 \mathrm{~m}$, respectively (Troester 1999).

In the karst NCL, as you move southward away from the coast, the base of the upper aquifer is the rising Cibao Formation. Compared to the upper aquifer, the Cibao has lower hydraulic conductivity and the water table has a steeper gradient. The saline water in the upper aquifer is truncated by the rising Cibao Formation. The GhybenHerzberg principle predicts that the slope of the salinefreshwater interface will be 40 times that of the water table (Vacher 1988).

The occurrence of saline water in the aquifer ends about where the land surface changes from flat alluvium to rugged, exposed limestone. The Ghyben-Herzberg principle predicts that when the freshwater is floating on top of the saline water most of the storage of freshwater will be below sea level. These conditions are more likely to happen in karst aquifers where the gradient of both the water table and the saline/freshwater interface are lower. Which recharged the aquifers more; the 1985 Mameyes rainfall event or the 2017 Hurricane Maria? How long does the system take to switch from devasting floods to water rationing or vice versa? This study will look at spatial and temporal patterns of low or high rainfall events and the associated groundwater levels.

Groundwater levels in an aquifer will rise if more water is entering than leaving. Rising groundwater levels can be caused by increasing rainfall, leakage from irrigation, or decreased pumping. Likewise, groundwater levels can fall if rainfall is decreasing, irrigation leakage is decreas- ing, or pumping is increasing. In coastal areas where the freshwater is floating on the denser saltwater the rising water levels in the ocean can cause groundwater levels to rise without increasing the total volume of freshwater in the aquifer.

Currently, the author is working on a three-part series of journal articles that will describe the current status of groundwater in Puerto Rico. This article is the first. The title of the second and third articles will be "Is the specific conductance of groundwater rising in Puerto Rico?" and "A comparison of the groundwater quality in southern and northern Puerto Rico" respectively. The majority of the data for all three articles is publicly available on the Internet pages of the United States Geological Survey (USGS).

\section{Methods}

This study uses data from Puerto Rico from non-pumping observation wells operated by the USGS. The locations of these stations are shown in Figure 1. The stations used to make the index have 100 or more water levels. The raw data are on the Internet (USGS 2018). The USGS typically collects data about 10 times per year so a station with 100 or more data has been visited for a decade or more. This study has data only from the main island of Puerto Rico and does not have data from the smaller, sparsely populated islands of Vieques and Culebra, which are part of the archipelago de Puerto Rico.

The lowest water level is given a zero and the highest a 100. All other water levels are prorated. If a station had more than one water level in a month then an average was calculated for the month. The first step to produce the index is to calculate the average of all the stations that have data for each month between December 1967 and January 2018. Second the index is a three-point running average of the monthly averages. If a single month had no groundwater level data, then the average was the average of the surrounding months.

The island of Puerto Rico was divided into three regions and a sub-index was calculated for each region. The three regions are the karst NCL, the non-karst SCP, and the non-karst ROP. In addition to the index, a graph was made showing the fraction of the wells with data for each year that reached record lows or highs in that year. The record highs were assigned positive numbers and the re- 
cord lows were assigned negative numbers.

\section{Results}

The index is based on data from 80 non-pumping observation wells. The total number of station-months with data are 14,886 which is 43 percent of the total possible. A person can visit about 1000 groundwater wells per year. The labor to produce these data was about 15 years with a cost of about 2.4 million dollars. The index was calculated for every month from January 1982 to December 2017. The SCP and NCL sub-indices are based on 30 stations while the ROP has 20. Due to lack of data in the early 1980 s, the NCL sub-index could not be calculated until October 1984.

The Groundwater Index for Puerto Rico from 1982 to 2017 is shown in Figure 2. The index is rising 0.203 points per year. The hypothesis is correct. The Pearson correlation coefficient is 0.182 which has a p-value of 0.00014 or $1 / 7000$. The peaks and valleys of the index are clearly associated with events on the surface.

In November 1985, after the Mameyes Landslide, the index locally peaks at 70.0 and then groundwater levels decline for nine years. The all-time low for the index was 16.1 in August 1994 during the period of water rationing in the San Juan metropolitan area. After the drought the index rises for 17 years until it hits the all-time high of 79.4 in September of 2011. The last six years have been a

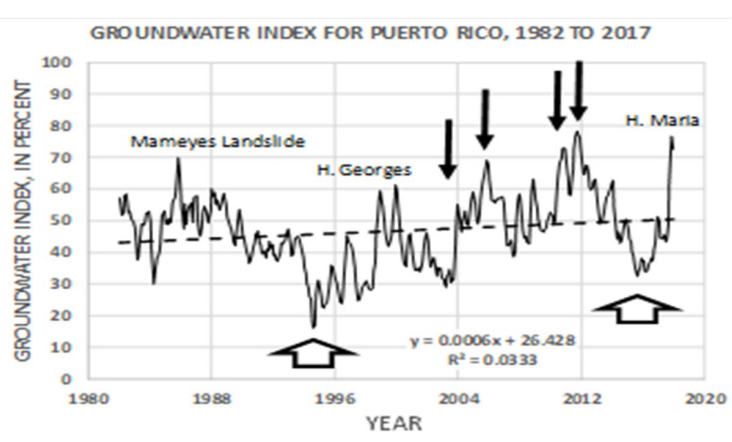

Figure 2. Groundwater Index for Puerto Rico, 1982 to 2017 . The trend is upward and is significant. The downward arrows are heavy rainfall events that did not include a hurricane or major landslide. The upward arrows are periods of water rationing in the San Juan Metropolitan Area. The slope shown on the graph is the change per day. roller coaster. The index drops for four years until it hits 32.4 in August 2015 only to rise to 79.0 in October 2017 after Hurricane Maria.

After Hurricane Maria the index hit its second highest value, but the hurricane caused the fastest rise in the index. The heavy rains of 2011 caused the index to rise above the maximum of 2010 by 4.7 points. In comparison the maximum of 2017 was 21.5 points higher than the maximum of 2016 .

The groundwater sub-index for the non-karst SCP aquifer is shown in Figure 3. The sub-index is falling 0.549 points per year. The Pearson correlation coefficient is -0.356 and the p-value is less than 0.00001 . Of the three major peaks, the all-time high was 94.4 in November 1985, the October 2011 sub-index was intermediate at 80.4, and after Hurricane Maria in December 2017 the sub-index was 72.8, the lowest of the three. In August 1995 the sub-index was 17.2 and 16.2 in August 2015. All of this is consistent with declining water levels.

The groundwater sub-indices for the karst NCL aquifer and the non-karst ROP are shown in Figures 4 and Figure 5. Both other sub-indices are less erratic than the SCP and are consistently rising. The results for the index and sub-indices are shown in Table 2. The all-time low for the NCL was March 1995 at 15.3. The all-time high for the NCL was 78.9 in August 2011. The all-time low for the ROP was 5.0 in March 1984 and the all-time high for the ROP was 81.4 in November of 2017.

The graph of the fraction of stations each year with record highs and record lows is shown in Figure 6. The

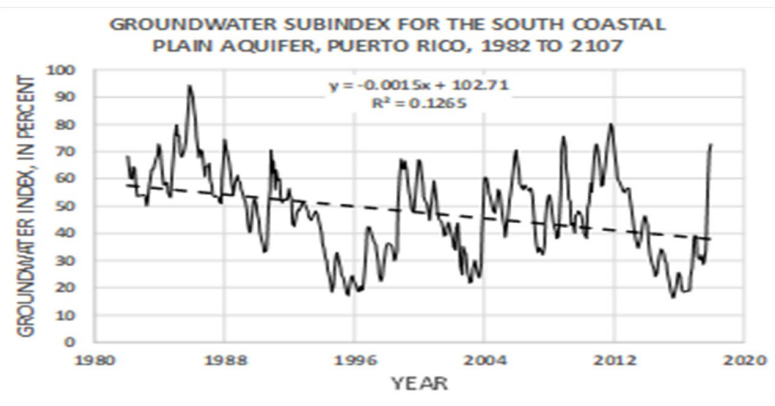

Figure 3. Groundwater sub-index for South Coastal Plain aquifer, 1983 to 2017. The trend is downward and is significant. The slope shown on the graph is the change per day. 


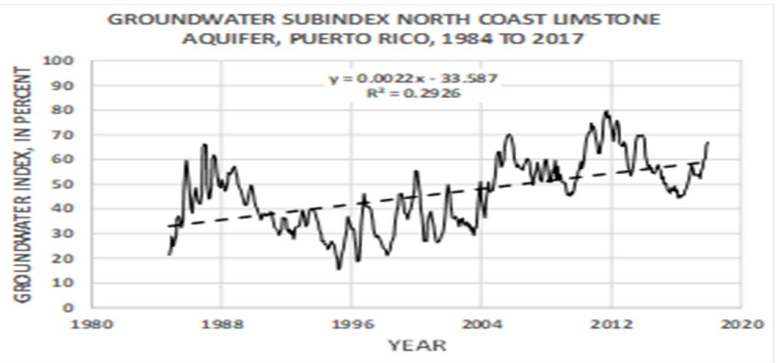

Figure 4. Groundwater sub-index for the North Coast Limestone aquifer, 1984 to 2017. The trend is upward and is significant. The slope shown on the graph is the change per day.

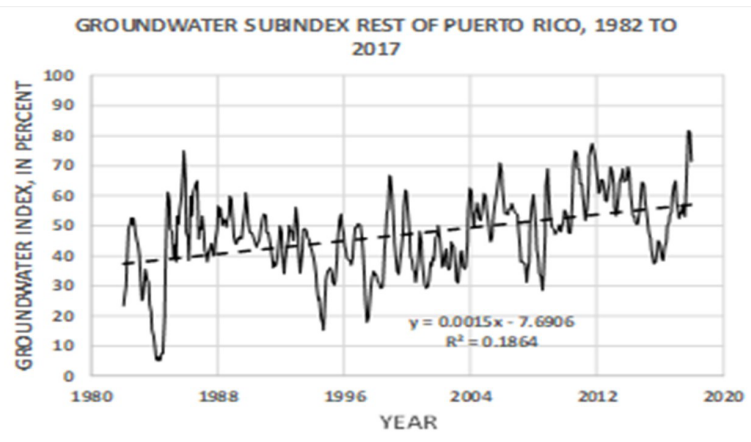

Figure 5. Groundwater sub-index for Rest of Puerto Rico, 1982 to 2017. The trend is upward and significant. The slope shown on the graph is the change per day.

\begin{tabular}{|l|r|r|c|}
\hline Region & Slope/year & Pearson & \multicolumn{1}{l|}{ p-value } \\
\hline Puerto Rico & 0.203 & 0.182 & 0.00014 \\
\hline SCP & -0.549 & -0.356 & $<0.00001$ \\
\hline NCL & 0.786 & 0.541 & $<0.00001$ \\
\hline ROP & 0.549 & 0.432 & $<0.00001$ \\
\hline
\end{tabular}

Table 2. Groundwater trends in Puerto Rico 1982 to 1987.

graph shows multi-year periods where it is dominated by either record highs or record lows, the two tend not to occur at the same time. Between 1993 and 1998 there are 37 stations that hit record low while only two hit record high. Between 2005 and 2013 there are 48 stations that hit record high and only four that hit record low.

\section{Discussion}

There is evidence that groundwater patterns in Puerto Rico have both spatial and temporal correlation. If rainfall events, either above or below average, where much smaller than the island then each station would rise and

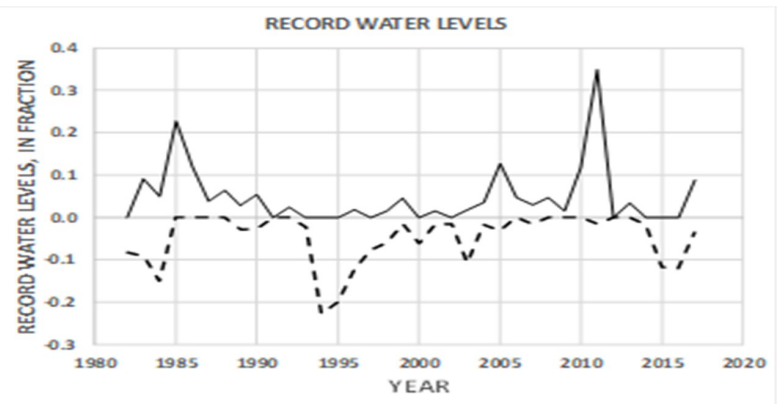

Figure 6. The fraction of the non-pumping observation wells that hit record highs or record lows in each year. The positive, solid line is the fraction of stations that hit record high water levels each year. The negative, dashed line is the fraction of stations that hit record low water levels each year. Between 1993 and 1998, 37 wells hit record lows while only two hit record highs. Between 2005 and 2011, 46 wells hit record highs and only four hit record lows.

fall independently of its neighbors as the valleys and peaks would cancel each other out and the index would stay close to 50 . If there was no temporal correlation then each month would be independent of the months around it and there would be no multi-year patterns in the data. Out of 20 stations, the ROP sub-index includes five stations in the drainage basin of Lago Carraizo and one above Lago La Plata. If droughts were small and restricted to a single basin than there would be no correlation between the groundwater level index and water rationing in the surface water system. The evidence is that both droughts and heavy rainfall events are at least the size of the island. In 2017 Hurricane Maria caused massive rainfall in all parts of the island.

Groundwater levels are rising everywhere in Puerto Rico except the non-karst SCP. The western part of the SCP near Ponce has permanent rivers and dams to provide surface water to the city. Near Santa Isabel and Salinas, the rivers are ephemeral, there are no suitable dam sites, and the area is more dependent on groundwater.

Groundwater levels are diverging with the non-karst SCP declining and the karst NCL and the non-karst ROP rising. This pattern could be caused by climate change,. but this would require that rainfall is declining in the south and rising in the majority of the island. The stations with erratic rainfall are in the south but even in the 
south the overall trend is towards increasing rainfall. Climate change is caused by human activities on a global scale. Human activities on a local scale could also be causing this divergence. An unintended consequence of the use of furrow irrigation in the SCP was the artificial recharge of the aquifer. With the switch from furrow to drip irrigation, less water was needed to irrigate crops and the artificial recharge was reduced or eliminated. The divergence could also be caused by different pumping patterns. Before invoking climate change, we need to better understand how irrigation and pumping practices have affected the groundwater levels.

Levels of groundwater in the SCP have been a roller coaster. Large scale groundwater production in the SCP began in the 1930s (Kuniansky et al. 2004). In Santa Isabel, in 1967 there was a drought and a cone of depression below sea level formed (Renken et al. 2002). By the 1980s heavy rains had eliminated groundwater levels below sea level. By 2003 the groundwater levels were once again below sea level (Kuniansky et al. 2004). The water levels in the Alomar 1 well in Santa Isabel are shown in Figure 7. The range of water levels in the well is $12.3 \mathrm{~m}$.

In Salinas the pattern is similar. In 1985, the potentiometric surface had a cone of depression to sea level but not below. The 1990s was a time of drought and by 2002 the water levels had dropped by as much as $4.9 \mathrm{~m}$. Heavy rains in November 2003 caused water levels to rise by about 2.9 m (Kuniansky and Rodríguez 2010). Hurricane Maria is the largest single recharge event but for most of the 25 years before Maria, the water level in the well was below sea level. Maria was a large recharge event, but it does not change the downward pattern over the 36 years of the sub-index.

At most stations that were used to develop the NCL and ROP sub-indices, it is unknown if the changes in groundwater levels are caused by changes in recharge, pumping or both. One exception is the Valle de Yabucoa, a small coastal valley filled with alluvium in southeastern Puerto Rico. In Yabucoa the Puerto Rico Aqueducts and Sewer Authority pumps wells near highway \#3 and for forty years an oil refinery pumped groundwater from wells closer to the coast. Troester and Richards (1996) documented that when the oil refinery reduced its consumption of groundwater the water levels in Yabucoa 7 rose. The water levels in the Yabucoa 7 well are shown in Figure 8. The range in the water levels is $8.32 \mathrm{~m}$. This

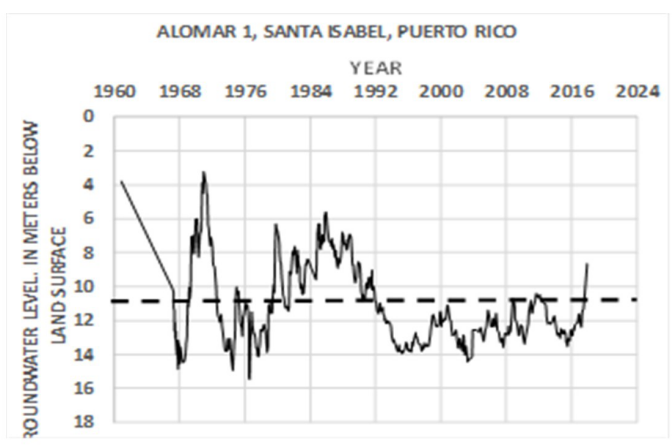

Figure 7. Groundwater levels at Alomar 1, Santa Isabel, Puerto Rico. The dashed line is sea level. The water levels dropped below sea level in the 1970s rose in the 1980s and have been below sea level almost continuously for more than 24 years.

station is part of the ROP sub-index. The oil refinery has been closed and demolished. The water levels in the well dropped in the 1970s but since 1980 have risen 6 meters.

Water levels in the Griv well in Arecibo are shown in Figure 9. The well is south of the Caño Tiburones wetland and near the Arecibo landfill. It is developed in the upper aquifer which has high hydraulic conductivity and for this reason the range in water levels is $945 \mathrm{~mm}$, an order of magnitude less than the other examples given.

The groundwater levels in the karst NCL have been rising for years. This raises the question if the rising groundwater is pushing the saline water out of the aquifer. The best place to answer this question is at Higuillar 1 where the elevation of the saline/freshwater interface was measured by borehole induction logging in 1995, a period of drought. By 2011 the water level had risen two meters. In 1995 the well had $78 \mathrm{~m}$ of fresh water floating on the saline water. If the system is at equilibrium, then the thickness of the freshwater may have doubled.

In the final analysis, the current pumping conditions in the karst NCL are sustainable because the population is falling, rainfall is increasing, the groundwater levels are rising, and the theory suggests that saline water is being pushed out of the aquifer. The current pumping conditions in the non-karst SCP are less sustainable because, as of 2010, the population was still growing, the rainfall is more erratic, and the groundwater levels are falling. In the ROP groundwater levels are rising but the population and rainfall data are erratic and there is no clear trend. 


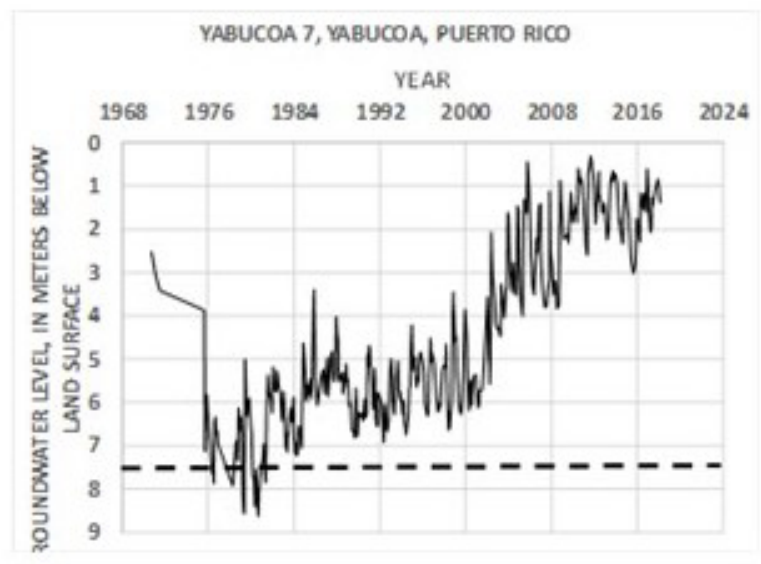

Figure 8. Groundwater levels at Yabucoa 7, Yabucoa, Puerto Rico. The dashed line is sea level. The water dropped in the 1970s but has been rising steadily since 1980 . The rising water levels in this well have been correlated with the decreasing pumping of groundwater at a now demolished oil refinery (Troester and Richards 1996).

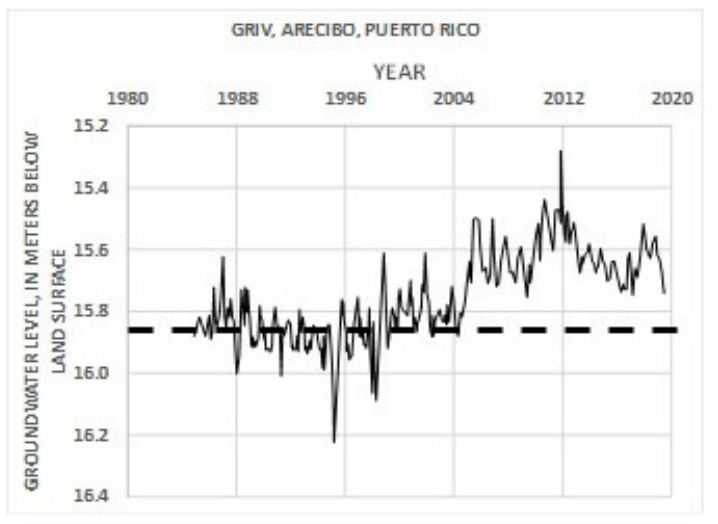

Figure 9. Groundwater levels at Griv well in Arecibo. The dashed line is sea level. The water level has been above sea level continuously since 2004. Prior to 2004 it was often below sea level.

Groundwater discharges from the aquifers in producing wells, springs, and seeps into riverbeds and wetlands. If groundwater levels are rising everywhere in Puerto Rico except the SCP then a logical hypothesis is that baseflow discharge in streams and the areal extent of wetlands are increasing. Coastal wetlands are important for birds, both migrant and permanent residents. Increasing groundwater levels will increase wetland habitats and may increase biodiversity.

\section{Conclusion}

Groundwater level data available on the Internet from 80 non-pumping observation wells operated by the USGS were used to create a monthly groundwater level index from 1982 to 2017. Sub-indices were created for the SCP, NCL, and the ROP. Groundwater levels are rising in all parts of Puerto Rico except the SCP. High values of the groundwater level index are associated with destructive events like hurricanes and landslides. Low values of the groundwater level index are associated with water rationing. The largest single recharge event was Hurricane Maria in 2017. In most of Puerto Rico it is unknown if the change in water levels is caused by changes in rainfall or pumping. In SCP cones of depression below sea level have repeatedly formed during droughts. In Yabucoa the groundwater levels rose after an oil refinery first reduced its consumption of groundwater and then closed completely. The current conditions under which groundwater is pumped are sustainable in the karst NCL but not in the non-karst SCP.

All the water levels used in this report were collected by the USGS and are available on Internet in National Water Information System (USGS 2018).

\section{References}

Criss D. Puerto Rico's power blackout is now the second-largest blackout on record. [Internet]. 2018. [Place of publication unknown] CNN [Cited 2 May 2018] Available from: https://edition.cnn. com/2018/04/16/us/puerto-rico-blackout-secondlargest-globally-trnd/index.html.

Helm R. United States Drought Monitor: Puerto Rico. [Internet] 2018. [Place of publication unknown] NOAA/NCEI [Cited 30 August 2019] Available from http://droughtmonitor.unl.edu/CurrentMap/ StateDroughtMonitor.aspx?PR.

Hernández AR. Exodus from Puerto Rico grows as island struggles to rebound from Hurricane Maria. [Internet] 2018. [Place of publication unknown] Washington Post [2 May 2018] Available from: https://www.washingtonpost.com/national/exodus- 
from-puerto-rico-grows-as-island-strugglesto-rebound-from-hurricane-maria/2018/03/06/ b2fcb996-16c3-11e8-92c9-376b4fe57ff7_story. html?noredirect $=$ on\&utm_term $=.2 \mathrm{fb} 6 \mathrm{~d} 9 \mathrm{ed} 83 \mathrm{~d} 4$.

Janssen H. Puerto Rico residents face water rationing that lasts up to 48 hours amid historic drought. [Internet]. 2015. Accuweather.com [Cited 8 February 2016] Available from: http:// www.accuweather.com/en/weather-news/ puertorico-drought-el-nino-tourism-local-waterrestrictions $/ 51647356$.

Kornikov LF. 2013. Ground water depletion in the United States (1900-2008). United States Geological Survey Scientific Investigations Report 2013-5079. Available on the Internet at https:// pubs.usgs.gov/sir/

Kuniansky EL, Gómez-Gómez F, Torres-González S. 2004. Effects of aquifer development and changes in irrigation practices on ground water availability in the Santa Isabel area, Puerto Rico. U.S. Geological Survey Water Resourc2013/5079/.es Investigations Report 03-4304, 56 p. Available on the Internet at https://pubs/usgs.gov/wri/ wri034303/.

Kuniansky EL, Rodríguez JM. 2010. Effects of changes in irrigation practices and aquifer development on groundwater discharge to the Jobos Bay National Estuarine Research Reserve near Salinas, Puerto Rico. United States Geological Survey Scientific Investigations Report 2010-5022, 106 p. Available on the Internet at http://pubs.usgs.gov/ sir/2010/5022/.

Larsen MC, 2000, Analysis of 20th century rainfall and streamflow to characterize drought and water resources in Puerto Rico, Physical Geography, 21:6(494-521).

Martínez-Sánchez O. 2014. Rainfall patterns across Puerto Rico: The 1980-2013 rate of change. National Weather Service, San Juan Puerto Rico. [Internet] [Cited 2 January 2020] pr-ccc.org/ download/Odalys-PRCCC_2014.pdf.

Molina-Rivera WL. 2014. Estimated water use in Puerto Rico. US Geological Survey Open-File Report 2014-1117 35p. Available on the Internet at https://pubs/usgs.gov/of2014/1117/.
Morris BL, Lawrence ARL, Chilton PJC, Adams B, Calow RC, Klinck BA. 2003. Groundwater and its susceptibility to degradation: A global assessment of the problem and options for Management. Early warning and assessment report series, RS. 03-3. United Nations Environment Programme, Nairobi, Kenya.

National Weather Service. PR and USVI Normals. [Internet] 2018. [Place of publication unknown] National Weather Service [Cited 5 June 2018] Available from: (http:/www.weather.gov/sju/ climo_pr_usvi_normals).

Notiuno630AM. Termina racionamiento de agua para quienes de sirven de Guajataca. [Internet]. 2019. [Place of publication unknown] Notiuno630 AM [Cited 30 August 2019] Available from: https:// www.notiuno.com/noticias/gobierno-y-politica/ termina-racionamiento-de-agua-para-quienessirven-de-guajataca/article_ecd0f788-7b3811e9bdd9-ab104fla9a5c.html.

Renken RA, Ward WC, Gill IP, Gómez-Gómez F, Rodríguez-Martínez J. 2002. Geology and Hydrogeology of the Caribbean Islands Aquifer System of the Commonwealth of Puerto Rico and the U.S. Virgin Islands: U.S. Geological Survey Professional Paper 1419. Reston, VA 139 p.

Richards RT, 2016, Using existing data to study the effects of the trade winds and aquifer vulnerability in Puerto Rico, Universidad Ana G. Méndez Gurabo Campus, unpublished doctoral dissertation.

Santos-Burgoa C, Goldman A, Andrade E, Barrett N, Colón-Ramos U, Edberg M, García-Meza A, Goldman L, Roess A, Sandberg J, Zeger S. Ascertainment of the Estimated Excess Mortality from Hurricane Maria in Puerto Rico. [Internet]. 2018. George Washington University Available from: https://hsrc.himmelfarb.gwu.edu/sphhs global_facpubs/288.

Silva-Tulla F. 1986. The October 1985 landslide in Barrio Mameyes, Ponce, Puerto Rico. National Academy Press. 14 p.

Troester JW, Richards RT. 1996. Geochemical properties and saline-water intrusion in the Valle de Yabucoa alluvial aquifer in southeastern Puerto Rico. United States Geological Survey Water- 
Resources Investigations Report 96-4188. San

Juan, Puerto Rico

Troester JW. 1999. Geochemistry and hydrogeologic framework of the saline-freshwater interface and the calculation of the net recharge in the Dorado area, north-central Puerto Rico. United States Geological Survey Water-Resources Investigations Report 98-4030. San Juan, Puerto Rico.

United States Census Bureau. 2020. [Internet] https:// www.census.gov (cited 15 January 2020.

United States Geological Survey. National Water Information System: Web Interface [Internet]. 2018. [Place of publication unknown] USGS [Cited 2 May 2018] Available from: https://waterdata.usgs.gov/pr/nwis/ current/?type $=$ gw\&group_key $=$ county_cd.

Vacher HL. 1988. Dupuit-Ghyben-Herzberg analysis of strip-island lenses. Geological Society of America Bulletin 100:580-591.

Yadav P. 2912. Ground water levels declining, contamination rising in Punjab. [Internet]. 2012. The Times of India. 28 June 2012 [Cited 13 July 2014] Available from: http://timesofindia. com/india/ground-water-levels-decliningcontamination-rising/articleshow/1442758.cms). 